\title{
Pengembangan Instrumen Penilaian Autentik pada Materi Segiempat Kelas VII
}

\author{
Efuansyah $^{1}$, Reny Wahyuni ${ }^{2}$ \\ 1,2 Mathematics Education, STKIP PGRI Lubuklinggau \\ e-mail: zxfe73@gmail.com
}

\begin{abstract}
ABSTRAK. Penelitian ini bertujuan untuk menghasilkan instrumen penilaian autentik dalam pembelajaran matematika materi geometri bidang datar kelas VII dalam hal aspek validitas dan kepraktisan serta untuk mengetahui pengaruh potensial. Penelitian ini menggunakan metode penelitian pengembangan (development research) jenis penelitian formatif yang melibatkan 32 siswa kelas VII SMP Negeri 24 Palembang. Dalam penelitian ini serangkaian instruksi dikembangkan melalui beberapa tahap self evaluation, expert reviews and one-to-one, small group, dan field tests. Penelitian ini menghasilkan penilaian otentik pada sifat-sifat, keliling dan luas persegi panjang. Penelitian ini mencakup serangkaian pembelajaran yang terdiri dari dua kegiatan pada sifat/karakteristik dan keliling \& luas persegi panjang. Hasil pengembangan instrumen penilaian otentik menunjukkan bahwa dengan mereka mengetahui bahwa mereka dinilai dengan tiga aspek (kognitif, afektif, dan psikomotor) siswa sangat antusias untuk belajar, menyelesaikan permasalahan dengan baik, respon berani dan bertanggung jawab menyampaikan gagasan baik tertulis maupun lisan terkait dengan persegipanjang.
\end{abstract}

Kata kunci: penilaian otentik, segiempat, penelitian pengembangan.

\begin{abstract}
This research aims to produce authentic assessment instruments in mathematics learning materials plan geometry class VII in terms of aspects of validity and practicality as well as to determine the potential effect. This study uses research development methods (development research) type of formative research involving 32 seventh grade students of SMP Negeri 24 Palembang. In this study a series of instruction developed through several stages of self evaluation, expert reviews and one-to-one, small group, and field tests. This research produces authentic assessment on the material properties of the material, the circumference and area of a rectangle. This study includes a series of learning consists of two activities on properties and circumference $\&$ area of a rectangle. The results of the development of authentic assessment instruments shows that with them knowing that they are assessed by three aspects (cognitive, affective, and psychomotor) students are very enthusiastic to learn, able to work on the problems with a good, brave respond and put forward the idea of both written and verbal are associated with a square long.
\end{abstract}

Keywords: authentic assessment,quadrilaterals, development research.

\section{PENDAHULUAN}

Materi segiempat merupakan salah satu pokok bahasan geometri (Rahayu, Purwoko, \& Zulkardi, 2008). Menurut (Yeni, 2011) geometri terkait erat dengan kehidupan kita sehari- 
hari. Pengajaran geometri dapat melatih berpikir secara nalar, oleh karena itu geometri timbul dan berkembang karena proses berpikir (Aini, 2008). Menurut (Wahyuni, Deniyanti, \& Meiliasari, 2013) bangun datar segiempat merupakan salah satu materi dalam matematika yang menyajikan fenomena visual yang bersifat abstrak. Selama ini guru mengajarkan geometri segiempat hanya menghafal definisi saja tanpa memahami makna dari definisi tersebut sehingga siswa sulit memahami sifat-sifat dan hubungan antara sifat dari bangunbangun segiempat tersebut (Yadil, 2009). Kebanyakan siswa kelas VII di SMP PIRI 1 Yogyakarta masih belum bisa mengidentifikasi segiempat dengan benar dan melakukan pemecahan soal yang berkaitan dengan segiempat (Andrianik, 2008). Dalam mengajarkan geometri segiempat, Hiele (1995) mengusulkan lima tahap belajar siswa dan peran guru dalam proses pembelajaran, yaitu tahap informasi, orientasi terarah, penegasan/uraian, orientasi bebas, dan integrasi. Keberhasilan suatu pembelajaran di sekolah tidak terlepas dari sistem penilaian yang dilakukan guru.Penilaian sangat berperan dalam menentukan arah pembelajaran dan kualitas pendidikan (Pantiwati, 2013). Namun, penilaian saat ini belum dapat dijadikan suatu tolak ukur keberhasilan belajar karena kebanyakan guru hanya menilai dari segi kognitif saja.Hasil penelitian (Pantiwati, 2013) tentang profil sistem penilaian oleh guru juga menunjukkan bahwa tes tertulis bentuk obyektif mendominasi instrumen pengukuran hasil belajar siswa.

Menurut (Sumaji, 2012) penilaian oleh guru seharusnya digunakan untuk mengumpulkan informasi sebanyak-banyaknya tentang kemajuan belajar peserta didik atau untuk mendorong peningkatan belajar peserta didik. Dorongan peningkatan belajar dapat berasal dari peserta didik sendiri yang telah mengetahui hasil penilaian itu, dan dapat juga dilakukan oleh guru yang telah memanfaatkan hasil penilaian itu untuk mengambil keputusan tentang pembelajaran peserta didiknya. Penilaian kompetensi dasar dilakukan berdasarkan indikator-indikator pencapaian hasil belajar, baik berupa domain kognitif, afektif, maupun psikomotor.Untuk itu penilaian yang sangat cocok untuk melakukan penilaian seperti itu adalah penilaian autentik (authentic assessment). Penilaian autentik merupakan penilaian langsung dan ukuran langsung (Mueller, 2006). Menurut (Hayat, 2006) penilaian autentik adalah proses pengumpulan informasi oleh guru tentang perkembangan dan pencapaian pembelajaran yang dilakukan anak didik melalui berbagai teknik yang mampu mengungkapkan, membuktikan, atau menunjukkan secara tepat bahwa tujuan pembelajaran dan kemampuan (kompetensi) telah benar-benar dikuasai dan dicapai.

Kurikulum 2013 adalah kurikulum yang dapat menghasilkan insan Indonesia yang produktif, kreatif, inovatif, afektif melalui penguatan sikap, keterampilan, dan pengetahuan yang terintegrasi (Kemendikbud, 2013). Proses pembelajaran pada kurikulum 2013 untuk jenjang SMP dan SMA menggunakan pendekatan saintifik yang mendorong siswa lebih mampu dalam mengamati, menanya, mencoba/mengumpul-kan data, menalar, dan berkomunikasi (Kemendikbud, 2013). Prinsip penilaian yang tercantum dalam Peraturan Menteri Pendidikan dan Kebudayaan RI No. 81A tahun 2013 tentang penilaian hasil belajar peserta didik pada jenjang pendidikan dasar dan menengah memiliki karakteristik penilaiannya adalah belajar tuntas, autentik, berkesinambungan, berdasarkan acuan kriteria, dan menggunakan teknik penilaian yang bervariasi. Teknik penilaian yang ada pada Kurikulum 2013 yaitu :(1) Unjuk Kerja; (2)Sikap; (3) Tertulis; (4) Project, (5) Produk; (6) Portopolio; (7) Penilaian diri.

Menurut Marheni (2011), pada dasarnya penilaian autentik adalah penilaian kinerja, yaitu suatu unjuk kerja. Observasi perilaku/aktivitas dilakukan oleh guru pada proses pembelajaran di kelas dengan lembar observasi (Setiani, 2011). Tes tertulis untuk mengukur penguasaan pengetahuan (Aisyah, 2007). Berlandaskan hal itu dalam penelitian ini, kami 
mengambil teknik penilaian tertulis (kognitif), unjuk kerja (psikomotor), dan sikap/observasi (afektif). Dari uraian singkat ini sangat jelas bahwa penilaian autentik merupakan bagian yang tak terpisahkan dengan kurikulum 2013. Karena penilaian autentik memandu pembelajaran melalui penyerasian berbagai aktivias belajar yang dilakukan siswa selama proses pembelajaran yang di dalamnya terkandung muatan karakter. Penilaian autentik memberikan gambaran nyata kemampuan siswa dalam matematika dan memberikan ukuran ketercapaian pengembangan karakter siswa. Dengan adanya hal itu, penulis tertarik melakukan penelitian tentang penilaian autentik yang berjudul "Pengembangan Instrumen Penilaian Autentik pada Materi Segiempat Kelas VII".

\section{METODE PENELITIAN}

Metode penelitian pengembangan (development research) ini bertujuan mengembangkan instrumen penilaian autentik yang valid dan praktis dalam pembelajaran geometri bangun datar segiempat di kelas VII. Tahapan pengembangan instrumen penilaian autentik ini terdiri dari dua tahapan utama yaitu tahapan preliminary (tahap persiapan) dan tahap formative evaluation. Langkah yang diambil mengikuti langkah-langkah yang dikemukakan oleh Tessmer (Zulkardi, 2002) yang meliputi (1) self evaluation, (2) prototyping (expert review, one-toone, dan small group), dan(3) field test.

Pada tahap preliminary, peneliti melakukan analisis materi pada pokok bahasan segiempat yang sesuai dengan kurikulum 2013 dan tuntutan lingkungan, observasi siswa, menghubungi guru di sekolah untuk mempersiapkan penjadwalan serta penyusunan tujuan. Selanjutnya peneliti mendesain instrumen penilaian yang meliputi membuat kisi-kisi, penulisan indikator, mencari materi segiempat yang sesuai dengan tujuan yang hendak dicapai dan penulisan instrumen dengan didasarkan pada prinsip-prinsip penilaian dalam kurikulum 2013.

Pada tahapan formative evaluation, tahap pertama dilakukan self evaluation yaitu peneliti melakukan penilaian sendiri terhadap hasil desain instrumen penilaian yang telah dibuat. Hasilnya disebut sebagai prototype I. Selanjutnya prototype I dicermati, dinilai, dan dievaluasi dari segi konten, konstruk, dan bahasa oleh pakar. Saran-saran dari pakar ditulis pada lembar validasi. Secara bersamaan, juga dilakukan tahap one-to-one. Pada tahap ini prototype I diujicobakan kepada tiga orang siswa sebagai tester yang diminta untuk mengerjakan soalsoal LAS dan soal individu kognitif) yang telah dikembangkan disamping itu juga mereka diminta untuk memberikan komentar terhadap soal yang telah mereka kerjakan. Hasil atau temuan yang diperoleh pada tahap expert review dan one-to-one dijadikan bahan pertimbangan dalam merevisi prototype I yang selanjutnya akan menghasilkan prototype II. Prototype II ini kemudian diujicobakan pada small group. Pada tahap ini, enam orang siswa diminta menyelesaikan soal-soal di prototype II serta diminta komentarnya terhadap soal yang telah dikerjakan. Komentar dan temuan pada tahap small group ini dijadikan landasan pertimbangan dalam merevisi Prototype II.

Hasil revisi prototype II dinamakan prototype III yang dijadikan prototype akhir untuk dilanjutkan ke tahap field test.Prototype akhir inilah yang diujicobakan kepada subjek penelitian yaitu siswa kelas VII.10 sebanyak 32 siswa dari SMPN 24 Palembang yang dilakukan pada semester ganjil 2014/2015. Selama proses field test dilakukan penilaian unjuk kerja (psikomotor), observasi (afektif), dan soal evaluasi individu (kognitif). Hasil penilaian ketiga ranah inilah yang merupakan penilaian autentik kurikulum 2013. 
Instrumen pengumpulan data yang digunakan dalam penelitian ini adalah lembar validasi, tes, dan tanggapan siswa (learning $\log$ ). Lembar validasi yang berisi hasil wawancara, pendapat para pakar, dan teman sejawat.Tes berupa soal bentuk uraian. Lembar validasi digunakan untuk mendapatkan informasi dari para ahli sebagai expert judgment untuk memberikan masukan dan saran tentang intrumen penilaian autentik yang dihasilkan. Tes dan learning log digunakan untuk mendapatkan informasi tentang kepraktisan dan keefektifan soal yang dikembangkan.

Teknik analisis data yang digunakan adalah hasil wawancara (pendapat para pakar, teman sejawat, dan tanggapan siswa dicatat untuk perbaikan instrumen penilaian autentik), analisis instrumen penilaian autententik kognitif (tes), psikomotor (unjuk kerja), dan afektif (kerja sama \& inisiatif) (divalidasi secara kualitatif bersama para pakar dan teman sejawat yang ditinjau dari sisi, konten, konstruk, dan bahasa), analisis hasil tes keefektifannya dilihat dari proses (dianalisis secara deskriptif kualitatif dan diobservasi menggunakan lembar observasi) dan skor observasi dikelompokkan dalam suatu kategori. Data hasil angket yang diperoleh akan dihitung perindikator), serta dengan menilai tingkat kelayakan instrumen, kualitas, dan ketepatan instrumen yang dihasilkan. Perangkat instrumen yang dikembangkan memperhatikan tiga kriteria valid, praktis, dan efektif. Instrumen dikatakan valid apabila hasil validasi dari pakar mengatakan bahwa instrumen penilaian autentik (penilaian kognitif, afektif, dan psikomotor) yang dikembangkan sudah valid baik dari segi konten, konstruk, dan bahasa. Selain itu, instrumen dikatakan praktis apabila instrumen yang dikembangkan dapat digunakan oleh semua praktisi pendidikan matematika dan para pakar yang menjadi validator instrumen menyatakan bahwa instrumen yang dikembangkan dapat diterapkan. Sedangkan instrumen dikatakan efektif (Akker, 1999) apabila para pakar dan praktisi berdasarkan pengalamannya menyatakan bahwa instrumen (penilaian autentik) mempunyai efek potensial terhadap kemampuan siswa.

\section{HASIL}

\section{Tahap Preliminary}

Pada tahap ini dilakukan analisis terhadap materi pada pokok bahasan segiempat yang sesuai dengan kurikulum 2013 dan tuntutan lingkungan, observasi siswa, menghubungi guru di sekolah untuk mempersiapkan penjadwalan serta penyusunan tujuan. Selanjutnya dilakukan proses pendesainan produk, desain instrumen penilaian yang meliputi pembuatan kisi-kisi, penulisan indikator, mencari materi segiempat yang sesuai dengan tujuan yang hendak dicapai dan penulisan instrumen dengan didasarkan pada prinsip-prinsip penilaian kurikulum 2013. Tahap-tahap tersebut bertujuan untuk mengidentifikasi dan memilih materi esensial yang akan dijadikan domain konten pada instrumen penilaian autentik yang dikembangkan. Setelah perangkat instrumen dikembangkan, tahap selanjutnya adalah mengembang-kan instrumen yang termasuk penilaian kognitif, afektif, dan psikomotor.

\section{Expert review}

Tahap I ini melibatkan beberapa validator yaitu Dr. Suhuri, M.Pd dari UPGRI Palembang, dan Dr. Budi Santoso, M.Si dari Unsri. Selain itu, beberapa teman sejawat yang ikut membantu memvalidasi soal-soal yang dikembangkan yaitu Ahmad Fikri, M.Pd guru matematika SMPN 1 Gunung Megang dan Harnoni, M.Pd guru matematika SMPN 2 Gunung Megang.

Proses validasi dilakukan melalui walktrough. Berdasarkan uji validasi oleh pakar dan teman sejawat maka dapat disimpulkan instrumen penilaian autentik yang dikembangkan 
sudah tergolong baik (valid), meskipun masih perlu perbaikan-perbaikan berdasarkan saran dan tanggapan validator.

Tabel 1. Saran Pakar terhadap Instrumen Penilaian Prototipe Pertama serta Keputusan Langkah Tindakan Revisi

\begin{tabular}{|c|c|c|c|}
\hline No & Nama \& Lembaga asal & Komentar / Saran & Keputusan \\
\hline & $\begin{array}{c}\text { Dr. Suhuri, M.Pd } \\
\text { Pascasarjana Universitas } \\
\text { PGRI Palembang }\end{array}$ & $\begin{array}{l}\text { - Sebutkan sumber instrumen yang } \\
\text { dikembangkan! Punya siapa? } \\
\text { - Mengapa harus dikembangkan? } \\
\text { - Apanya yang dikembangkan? } \\
\text { - Modifikasi instrumen tersebut! } \\
\text { - Sesuaikan dengan kemampuan } \\
\text { peserta didik. } \\
\text { - Instrumen yang telah dimodifikasi } \\
\text { adalah milik pengembang instru-men } \\
\text { ini. } \\
\text { - Uji cobakan instrumen ini sampai } \\
\text { "fit" }\end{array}$ & $\begin{array}{l}\text { - Setuju } \\
\text { - Ada di bab III. } \\
\text { - Ada di bab III } \\
\text { - Setuju } \\
\text { - Setuju, dan dilaku-kan } \\
\text { penyesuaian. } \\
\text { - Setuju } \\
\\
\text { - Setuju, akan dilak- } \\
\text { sanakan }\end{array}$ \\
\hline & $\begin{array}{c}\text { Dr. Budi Santoso, M.Si } \\
\text { Pascasarjana Universitas } \\
\text { Sriwijaya }\end{array}$ & $\begin{array}{l}\text { - Untuk Observasi kerja pen.(F3) } \\
\text { bagaimana mengaitkan pengamatan } \\
\text { dengan nilai yang diberikan! } \\
\text { - Begitu juga penilaian unjuk kerja, } \\
\text { bagaimana mengaitkan elemen yang } \\
\text { tertulis dengan nilai yang diperoleh! } \\
\text { - Soal individu } \\
\text { *Perbaiki petunjuk belajar yang lebih } \\
\text { umum. } \\
\text { *Skor tidak mesti 100, jumlah } \\
\text { disesuaikan dengan tingkat } \\
\text { kesukaran soal. } \\
\text { - Perbaiki bahasa }\end{array}$ & $\begin{array}{l}\text { *Telah diperbaiki } \\
\text { * Setuju, disesuaikan }\end{array}$ \\
\hline
\end{tabular}

Berdasarkan tabel 1 di atas, saran dari para pakar diterima. Selanjutnya prototype I diperbaiki sesuai dengan saran dari pakar. Sehingga diharapkan kualitas dari produk yang dihasilkan dapat lebik baik.

\section{One-to-one}

Bersamaan dengan proses validasi dari para validator dan teman sejawat, prototype I juga diujicobakan pada tiga siswa kelas VII yang berasal dari sekolah yang sama yaitu SMPN 24 Palembang namun, memiliki kemampuan yang berbeda-beda yaitu tinggi, sedang, dan rendah. Ketiga siswa tersebut adalah M. Taufik Hidayat, Fiorena Tabina Aztur, dan Lendy. Selain diminta untuk mengerjakan soal LAS dan individu (kognitif), siswa juga diminta untuk mengomentari soal-soal yang telah dikerjakan. Tujuannya adalah untuk melihat kepraktisan soal.

Ketiga siswa tersebut diminta untuk mengerjakan soal uraian selama dua kali pertemuan masing-masing 90 menit. Selain itu, siswa juga diminta untuk menjawab beberapa pertanyaan terkait soal-soal yang telah dikerjakannya melalui wawancara langsung. Jawaban siswatersebut akan digunakan sebagai dasar untuk memperbaiki prototype I. One to One dilakukan untuk melihat keterbacaan penggunakan prototype dari segi siswa, bagaimana siswa dapat mengerti dengan penggunaan instrumen tersebut sehingga dapat memudahkan siswa dalam mendalami materi segiempat. Berdasarkan saran/komentar dari para pakar, 
teman sejawat, dan one-to-one yang telah didapatkan, maka instrumen autentik pada prototype I diperbaiki dan direvisi kembali.

\section{Small group}

Tahap ini bertujuan untuk melihat kepraktisan soal-soal pada prototype II. Uji coba small group dengan melibatkan enam siswa kelas VII SMPN 24 Palembang. Siswa-siswi tersebut diminta untuk mengerjakan soal LAS dan individu yang diberikan peneliti. Setelah mengerjakan soal-soal uraian tersebut, siswa diminta untuk memberikan komentar tentang soal-soal yang telah dikerjakan dengan menuliskannya pada lembar yang telah disediakan.

Hasil uji coba small group, diketahui bahwa ada beberapa perintah soal dan soal yang diberikan peneliti memerlukan revisi kembali. Namun secara umum soal-soal yang dikembangkan telah praktis. Komentar dan keputusan langkah yang diambil berdasarkan uji coba small group dapat dilihat dalam tabel 2.

Tabel 2. Komentar dan Keputusan Revisi

\begin{tabular}{|c|c|c|}
\hline Nama Siswa & Komentar/Permasalahan & Keputusan \\
\hline $\begin{array}{l}\text { Sendy } \\
\text { Ivan Fadila } \\
\text { Vina Aztur } \\
\text { Reza Irawan } \\
\text { Riska } \\
\text { Ayu Wulandari }\end{array}$ & $\begin{array}{l}\text { - Perintah melakukan aktivitas sifat persegi } \\
\text { panjang (SP) belum jelas. } \\
\text { - Perintah no } 1 \text { (SP) agak membi-ngungkan. } \\
\text { - Perintah no } 2 \text { agak sulit dipahami. } \\
\text { - Minta dijelaskan lebih lanjut perintah no } \\
\text { 3. } \\
\text { - Salah konsep dalam menuliskan nama } \\
\text { panjang sisi pada soal no } 4 \text { dan } 5 . \\
\text { - Belum memahami konsep sudut dan } \\
\text { kesamaan sudut. } \\
\text { - Perintah soal individu sifat persegi } \\
\text { panjang agak bingung. } \\
\text { - Soal individu 1a agak janggal memberi } \\
\text { nama persegi panjangnya. } \\
\text { - Soal 1c belum mengerti hubungan } \\
\text { panjang sisi persegi panjang yang } \\
\text { diketahui dengan perintahnya. } \\
\text { - Masalah no } 1 \text { pada LAS Kll \& luas belum } \\
\text { jelas. } \\
\text { - Perintah no } 2 \text { pada LAS luas belum jelas } \\
\text { - Pertanyaan bagian f pada LAS keliling } \\
\text { agak membingungkan. } \\
\text { - Pertanyaan g pada LAS keliling sulit } \\
\text { dimengerti. }\end{array}$ & $\begin{array}{l}\text { - Akan diberikan pemahaman } \\
\text { konsep sudut. } \\
\text { - Telah diperbaiki } \\
\text { - Telah diperbaiki } \\
\text { - Telah diperbaiki }\end{array}$ \\
\hline
\end{tabular}

\section{Field Test}

Setelah diperoleh prototype III yang valid dan praktis, maka dilakukan field test untuk melihat efek potensial terhadap kemampuan kognitif, psikomotor, dan afektif siswa selama proses field test.Pelaksanaan field test dilakukan pada tanggal 23 dan 30 Oktober 2014 di kelas VII.10 SMPN 24 Palembang dengan jumlah siswa sebanyak 32 siswa. Field test ini dilaksanakan sebanyak dua kali pertemuan dengan setiap kali pertemuan mengerjakan satu LAS secara berkelompok dan satu soal individu secara sendiri-sendiri selama tiga jam pembelajaran. Setiap siswa diminta menyelesaikan atau menjawab soal-soal yang diberikan dengan menuliskan langkah pengerjaan mereka yang mendukung jawaban tersebut. 
Hasil tes untuk soal sifat-sifat persegi panjang

Respon siswa A :

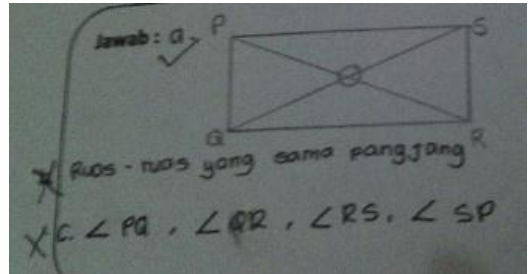

Gambar 1.a. Jawaban Salah

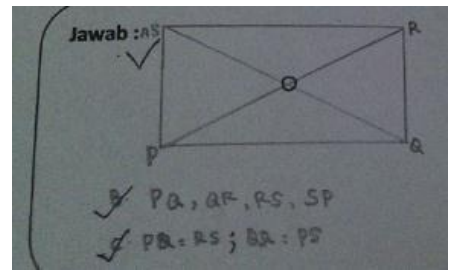

Gambar 1.b. Jawaban Benar

Berdasarkan gambar 1.a. di atas terlihat bahwa siswa salah dalam menuliskan jawaban pertanyaan, siswa diminta untuk menuliskan sisi-sisi yang terdapat pada segiempat. Hal ini terlihat bahwa siswa tersebut belum memahami konsep unsur-unsur pada segiempat. Hal ini berbanding terbalik dengan gambar 1.b. pada gambar 1.b terlihat bahwa siswa telah memahami maksud soal dan mengerti perintah dari soal tersebut.

Soal no 2 terdiri dari tiga sub-soal yaitu :

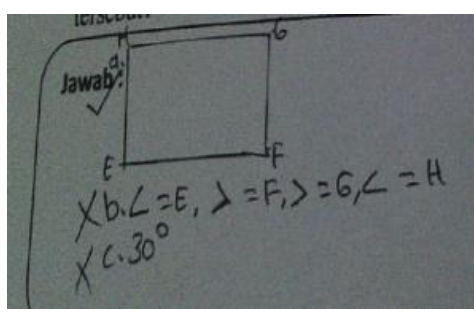

Gambar 2.a. Jawaban Salah

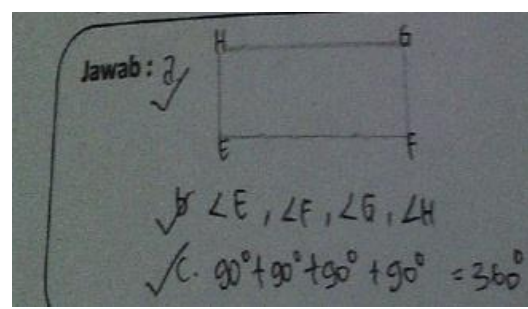

Gambar 2.b Jawaban benar

Berdasarkan gambar 2.a dan 2.b di atas terlihat bahwa masih ada siswa yang salah dalam menjawab soal. Pada gambar 2.a siswa salah dalam menentukan sudut-sudut yang terdapat pada persegi panjang dan siswa pun salah dalam menentukan besar sudut yang terdapat pada persegi panjang, hal ini dikarenakan kurang teliti siswa dalam memahami soal. Sedangkan pada gambar 2.b. terlihat bahwa siswa telah memahami soal dengan baik dan mampu menerjemahkan soal ke dalam bentuk matematika. Secara keseluruhan untuk materi sifat-sifat persegi panjang ini memiliki rata-rata kelas sebesar 76,765 terkategori baik.

Hasil tes untuk soal luas dan keliling persegi panjang

Pada pertemuan kedua tanggal 30 oktober peneliti melakukan field test yang kedua yang didahului dengan mengerjakan LAS secara berkelompok. Soal tes yang diberikan berupa satu soal untuk luas daerah persegi panjang dan satu soal untuk keliling daerah persegi panjang.

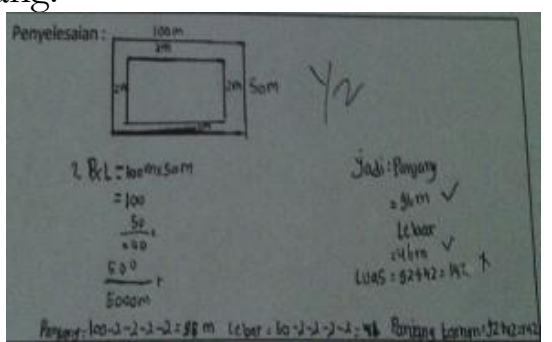

Gambar 3.a. Jawaban Salah

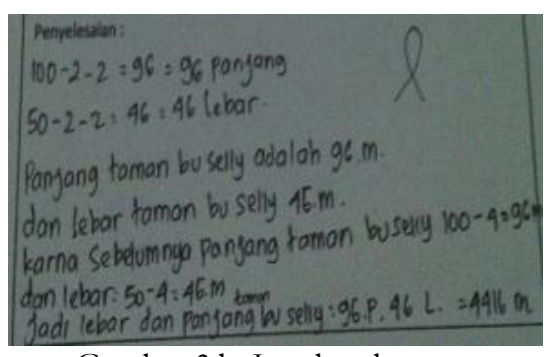

Gambar 3.b. Jawaban benar

Pada gambar 3.a merupakan salah satu jawaban siswa yang kurang teliti dalam menjawab soal. Pada soal ini siswa diharapkan mampu membuat model matematikanya terlebih dahulu, ketelitian sangat dibutuhkan dalam menjawab soal ini. Pada gambar 3.b. 
terlihat bahwa siswa benar dalam menjawab soal. Namun, sejauh ini nilai rata-rata kelas VII.10 mendapat nilai sebesar 74,84 yang tergolong predikat "Baik" untuk bahasan keliling dan luas persegi panjang ini.

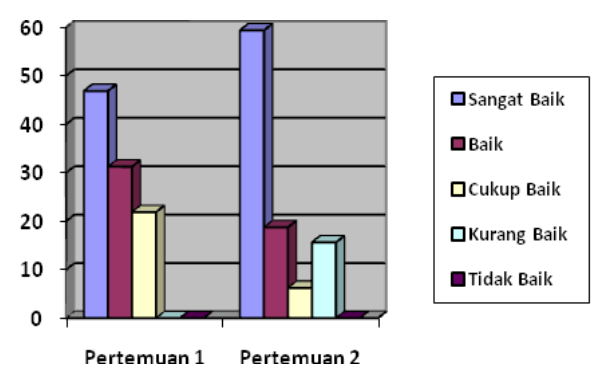

Grafik 4. Hasil Field Test Persegi

Pada gambar 4, terlihat jelas bahwa pada field test pertama siswa yang dapat menjawab dengan "sangat baik" sebanyak 46, 875\% atau sejumlah 15 orang, yang dapat predikat "baik" sebesar 31,25\% atau sebanyak 10 orang, dan "cukup baik" dengan persentasi $21,875 \%$ atau sebanyak 7 orang. Pada field test kedua banyak siswa yang mendapatkan predikat "sangat baik" sejumlah 19 orang atau 59,375\%, dengan predikat "baik" berjumlah 6 orang atau 18,75\%, predikat"cukup baik" berjumlah 2 orang atau 6,25\%, dan "kurang baik" berjumlah 5 orang atau 15,625\%. Baik field test pertama maupun kedua banyak siswa yang telah mendapat predikat minimal "baik" memiliki persentasi minimal 78\%.

\section{Hasil dan Analisis Observasi Unjuk Kerja Siswa Saat Proses (Psikomotor)}

Observasi dilakukan selama proses pembelajaran sebanyak $2 \mathrm{x}$ pertemuan dengan menggunakan lembar observasi dan lembar unjuk kerja pada saat siswa bekerja dalam kelompoknya.

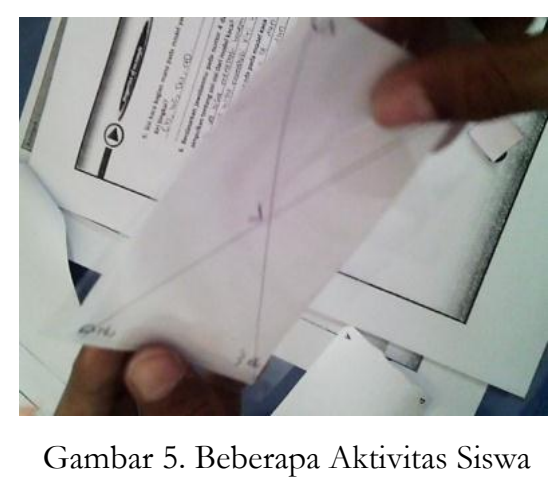

Dari 5 kategori unjuk kerja yang diamati pada pertemuan pertama, terlihat bahwa 17 orang siswa yang mendapat nilai "Sangat Baik", 14 orang siswa mendapat nilai "Baik", dan 1orang siswa yang mendapat nilai "Cukup Baik". Sedangkan pada pertemuan kedua terlihat bahwa 13 orang siswa yang mendapat nilai "Sangat Baik", 15 orang siswa yang mendapat nilai "Baik", 3 orang siswa yang mendapat nilai "Cukup Baik", dan 1 orang siswa yang mendapat nilai "Kurang Baik". Dari hasil yang diperoleh kategori unjuk kerja pada dua pertemuan tergolong telah "Baik". 


\section{PEMBAHASAN}

\section{Kevalidan}

Berdasarkan hasil validasi pakar yang meninjau tiga karakteristik yaitu bahasa, content dan konstruk dikatakan valid. Hal ini didasarkan pada landasan teori yang kuat dan komponen-komponen dalam instrumen penilaian saling berkaitan secara konsisten.Instrumen penilaian kognitif, afektif, dan psikomotor yang didesain sudah mengacu pada prinsip-prinsip penilaian kurikulum 2013 dan penilaian sebagai berikut :

1. Tujuan utama tes adalah meningkatkan proses belajar mengajar atau pembelajaran yang sedang berlangsung. Maksudnya guru haruslah mengukur kemajuan siswa dalam bentuk evaluasi formatif. Soal-soal diberikan baik secara lisan maupun tertulis. Proses pengerjaannya juga dapat secara individu maupun kelompok.

Contoh :

Soal yang diberikan bentuk kegiatan yang dilakukan secara kelompok dan terintegrasi dalam pembelajaran.

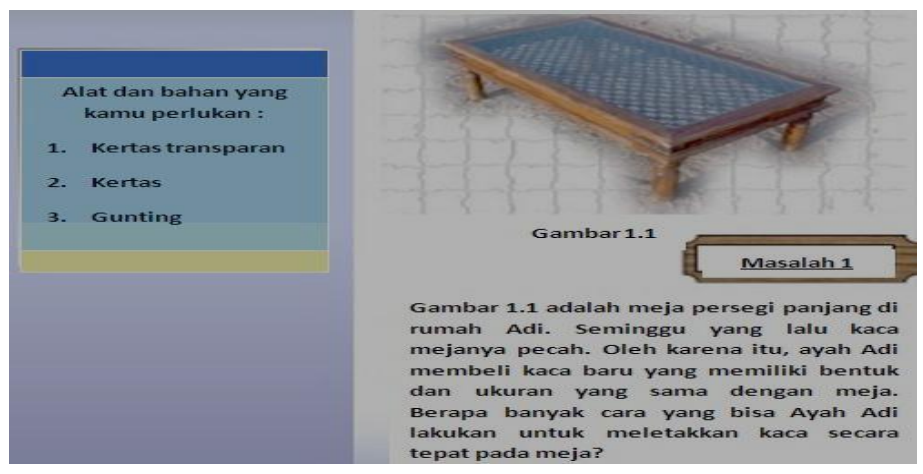

Gambar 6.Soal LAS

Pada gambar 6 di atas merupakan salah satu soal pada Lembar Aktivitas Siswa, sebelum siswa diminta untuk mengerjakan soal-soal yang ada pada LAS tersebut, maka siswa terlebih dahulu melakukan aktivitas yang mendukung pemahaman mereka mengenai materi segiempat. Pada gambar 4 di atas soal-soal yang diberikan merupakan soal yang terintegrasi dengan kehidupan sehari-hari siswa, sehingga siswa dapat lebih mudah memahami materi tersebut.

2. Metode penilaian harus memungkinkan siswa mendemonstrasikan apa yang mereka mampu daripada apa yang mereka tidak tahu (tes positif). Dengan cara itu, mereka akan belajar masing-masing jawaban dalam diskusi yang dibimbing oleh guru. Dalam situasi ini siswa diharapkan belajar hidup berdemokrasi dengan jalan saling belajar menghargai strategi masing-masing dan akhirnya mengakui bahwa jawaban teman lebih baik daripada jawabannya.

3. Soal-soal harus mengoprasionalkan tujuan pembelajaran yang ingin dicapai sebanyak mungkin.

4. Kualitas sebuah tes jangan hanya didefinisikan oleh bisa diakses atau tidak terhadap pemberian skor objektif. 
Instrumen soal yang dikembangkan ini tidak terbatas pada pemberian skor objektif tetapi juga dikembangkan instrumen soal yang penilaiannya berdasarkan tingkatan menurut kisi-kisi soal dan sistem penilaian. (terlampir).

5. Tes tersebut harus praktis, mudah didapat, tidak mahal dan sesuai dengan situasi lingkungan sekolah.

Selain didasarkan pada rasional teoritik yang kuat, validitas juga dilakukan pada penilaian pakar. Hasil penilaian pakar yang didukung oleh hasil uji coba masing-masing prototipe telah dijelaskan pada proses pengembangan instrumen. Dari validitas secara teoritik dan penilaian pakar maka dapat dikatakan bahwa instrumen yang dikembangkan valid.

\section{Kepraktisan}

Setelah instrumen penilaian divalidasi dan hasilnya dinyatakan valid dengan beberapa revisi, maka tahap selanjutnya dilakukan praktikalitas. Dari deskripsi dan analisis data berdasarkan hasil observasi, wawancara oleh validator, komentar siswa, menunjukkan praktikalitas instrumen penilaian dalam Kurikulum 2013 pada materi segiempat persegi panjang adalah praktis.

Untuk membuktikan instrumen penilaian adalah praktis, yaitu berdasarkan hasil analisis data secara deskrptif pada bab hasil penelitian sebelumnya.

a. Hasil observasi di lapangan bahwa siswa dan guru (peneliti) dapat melaksanakan aktivitas yang dicantumkan pada RPP dan menjalankan baik sebagai motivator, fasilitator maupun pembimbing kegiatan diskusi.

b. Berdasarkan hasil learning log (komentar siswa), secara umum dapat dinyatakan praktis meskipun masih ada kendala yang masih perlu diperbaiki.

Beberapa komentar M. Taufik Hidayat (one-to-one evaluation) jika dikaitkan dengan prinsip penilaian kurikulum 2013 yaitu :

1. “....... aku senang belajar seperti ini karena aku baru sadar kalau sifat-sifat persegi panjang selama ini tidak terlalu dianggap namun, sekarang aku benar-benar mengerti maksud sifat-sifat persegi panjang". Komentar ini mengidentifikasikan bahwa pembelajaran menggunakan LAS dan soal individu ini telah sesuai dengan kurikulum 2013 yang membuat anak dapat memahami/menemukan sendiri pemecahan masalah yang dihadapinya.

2. "Rumus keliling dan luas selama ini di waktu SD hanya dikasih guru tapi aku puas sekarang karena aku bisa menemukan sendiri". Komentar ini mengidentifikasikan bahwa soal mengarahkan siswa untuk belajar dan menemukan sendiri pemecahan/solusi dari masalah.

Beberapa komentar pada small group jika dikaitkan dengan karakteristik soal yang baik, yaitu:

1. "Aku senang belajar hari ini menambah wawasan juga tentang persegi panjang". Ini berarti bahwa LAS dapat membantu mempermudah mengerjakan soal individu sehingga lebih bermakna dan bernilai guna.

2. "Perintah melakukan aktifitas sifat persegi panjang belum bisa dimengerti. Perintah no. 1 membingungkanku juga. Untung ngerjainyo samo-samo jadi biso saling tanyo kalau dak ngerti”. Ini artinya bahwa instrumen yang dikembangkan juga menuntut berpikir tingkat tinggi. 
Analisis dari komentar inilah yang merupakan potential effect pengembangan instrumen sehingga memberikan indikasi bahwa instrumen yang dikembangkan cukup praktis.

Beberapa komentar pada field test jika dikaitkan dengan pembelajaran kurikulum 2013 yaitu :

1. "Aku dulu cuma tau rumus be, tp sekarang aku tau dari mano rumus itu berasal". Komentar ini menunjukkan bahwa siswa dapat bereksplorasi sendiri maupun secara kelompok sehingga mereka dapat memahami sendiri suatu pengetahuan.

2. "Kami disuruh mengerjakan LAS menyenangkan walaupun pak gurunya tidak menjelaskan secara detil di papan tulis, tp dari LAS ini kami bisa memahami materi persegi panjang dengan baik". Komentar ini berindikasi bahwa materi yang disajikan dalam LAS sesuai dengan tuntutan kurikulum 2013 yang membuat anak bereksplorasi.

3. "Kelompokku cukup aktif, setiap anggota bekerja bersama mencari dan menemukan sesuatu sesuai perintah LAS, petunjuk-petunjuknya jelas, sehingga soal sukarpun terlihat muda". Komentar ini menunjukkan bahwa dalam pembelajaran mereka saling membutuhkan sehingga terjadi kekompakkan dalam kelompok yang hal ini sesuai dengan kurikulum 2013 pada aspek kerjasama.

4. "Gurunya tidak menjelaskan materi secara penuh. Tapi untungnya aku sekelompok dengan kawan-kawan yang saling mendukung, jadi kalau ado kawan yang dk ngerti, kawan yg ngerti ngajari sehingga kami bisa semua materi persegi panjang itu". Komentar ini menunjukkan bahwa materi sesuai dengan tuntutan kurikulum 2013.

Komentar siswa dari one-to-one hingga field test menunjukkan bahwa instrumen yang dikembangkan dapat dikatakan praktis.

\section{Keefektifan}

Pelajaran yang efektif dimulai dari mempertimbangkan bagaimana kondisi anak, bukan bagaimana kondisi guru, yakni mengajar harus dimulai dengan ide-ide yang telah dimiliki oleh anak. Pengalaman belajar yang diperoleh siswa dari aktivitas yang memungkinkan siswa berinteraksi dengan soal, teman, dan guru, bereksplorasi, berkomunikasi, mengemukakan/bereksplorasi gagasan atau bertanya, beragumentasi, mengamati, dan mengasosiasi. Ide-ide matematika adalah hasil dari pengalaman penyelesaian soal dan bukan bagian yang harus diajarkan sebelum penyelesaian soal. Oleh karena itu kurikulum 2013 mengisyaratkan agar proses pembelajaran dimulai dengan pengajuan masalah. Selanjutnya proses penyelesaian soal berpadu dengan proses pembelajaran (prinsip penilaian autentik : peserta didik diminta mengumpulkan informasi dengan pendekatan scientific, memahami aneka fenomena atau gejala dan hubungannya satu sama lain secara mendalam, serta mengaitkan apa yang dipelajari dengan dunia nyata yang ada di luar sekolah).

Keefektifan instrumen dilihat dari :

a. Hasil analisis jawaban siswa (strategi dan solusi) yang diberikan, menunjukkan bahwa keberagaman siswa berbanding lurus dengan keragaman pola pikir mereka. Hal ini disebabkan bahwa instrumen penilaian yang dikembangkan tidak hanya menilai dengan pemberian skor objektif tetapi juga menggunakan cara-cara alternatif penilaian lainnya. Ada juga soal yang tidak terjawab oleh siswa terutama menentukan kesamaan sudut. Hal 
ini disebabkan mereka belum terbiasa melihat sudut dari sudut pandang yang berbeda yang membutuhkan analisis untuk menyelesaikannya.

b. Melihat rata-rata hasil uji coba prototipe ketiga adalah 75,802 terkategori "baik" dimana hampir semua siswa dapat menjawab soal-soal yang diberikan dengan baik meskipun ada 1-2 soal pada tiap pertemuannya yang belum bisa dijawab oleh siswa.

c. Hasil observasi saat aktivitas berlangsung menunjukkan bahwa siswa mencoba memahami soal dengan idenya sendiri terlebih dahulu kemudian memperluas ide-ide dan berkembang pemahamannya saat mereka mendengar, mendiskusikan ide, membuat gambar, mempertahankan penyelesaian, memikirkan strategi teman-temannya lewat diskusi. Aktivitas ini timbul karena desain soal yang memungkinkan siswa mendemonstrasikan apa yang mereka mampu daripada apa yang mereka tidak tahu (tes positif). Dari hasil lembar observasi diperoleh rata-rata persentasi keaktifan sebesar 92,875 yang terkategori aktif.

d. Learning $\log$ yaitu komentar bebas yang merupakan refleksi diri siswa terhadap pembelajaran dan instrumen penilaian. Hasil learning log diperoleh bahwa kebanyakan siswa yang diizinkan bekerjasama dalam kelompok serta mengeluarkan pendapat/ide secara bebas dalam LAS, mereka merasakan memperoleh keyakinan dan kepercayaan diri, berani mengambil resiko, mengkomunikasikan ide sendiri dan pada akhirnya senang mengerjakan matematika. Penyebab sikap positif terhadap matematika ini timbul karena permasalahan dan soal yang didesain memenuhi prinsip-prinsip penilaian autentik.

e. Hasil wawancara dengan guru senior mengatakan bahwa instrumen penilaian autentik ini efektif digunakan dan merupakan bagian dari pembelajaran, hanya saja harus didukung dengan kesiapan siswa dari rumah untuk mengefisienkan waktu.

Dari ketiga hal itu maka instrumen penilaian dapat dikatakan valid, praktis dan efektif serta berpengaruh potensial untuk subjek penelitian pada waktu instrumen diuji cobakan.

\section{DAFTAR PUSTAKA}

Aini, T. (2008). Penerapan Model Pembelajaran Van Hiele dalam Membantu Siswa Kelas IV SD Membangun Konsep Segitiga. Dipetik Januari 27, 2014, dari http://lppm.ut.ac.id/jp/72sept06/01 husnaeni.pdf/

Aisyah, N. (2007). Pengembangan Pembelajaran Matematika SD. Jakarta: Departemen Pendidikan dan Kebudayaan Direktorat Jendral Pendidikan Tinggi.

Akker, V. (1999). Principle and Methods of Development Research. Dordrecht: Kluwer.

Andrianik, A. (2008). Upaya Meningkatkan Motivasi dan Minat Belajar Siswa melalui Pendekatan Realistik pada Segiempat Kelas VII di SMP Piri 1 Yogyakarta. Yogyakarta: Skripsi tidak Diterbitkan.

Hayat, B. (2006). Assessment Berbasis Kelas. Jakarta: Pusat Penilaian Pendidikan Balitbang Depdiknas.

Kemendikbud. (2013). Pedoman Penilaian Hasil Belajar. Jakarta: Kemendikbud.

Marhaeni, A. A. (2011). Asesmen Otentik dalam Rangka KTSP, Suatu Upaya Pemberdayaan Guru dan Siswa. Universitas Pendidikan Ganesha.

Mueller, J. (2006). Authentic Assessment. Dipetik Februari 10, 2014, dari http://jonatan.muller.faculty.noctrl.edu/toolbox/whatisist.htm/

Pantiwati, Y. (2013). Hakekat Asessment Autentik dan Penerapannya dalam Pembelajaran Biologi. Jurnal Edukasi Matematika dan Sains, 1(1). 
Rahayu, T., Purwoko, \& Zulkardi. (2008). Pengembangan Instrumen Penilaian dalam Pendidikan Matematika Realistik Indonesia (PMRI) di SMPN 17 Palembang. Jurnal Pendidikan Matematika, 2(2).

Setiani, F. (2011). Pengembangan Asesmen Alternatif dalam Pembelajaran Matematika dengan Pendekatan Realistik di Sekolah Dasar. Jurnal Penelitian dan Evaluasi Pendidikan, 15(2).

Sumaji. (2012). Pengembangan Perangkat Pembelajaran Matematika Melalui Pendekatan Kontekstual dengan Penilaian Portofolio. Ponorogo: Universitas Muhammadyah Ponorogo.

Wahyuni, S. E., Deniyanti, P., \& Meiliasari. (2013). Mengembangkan Kemampuan Berpikir Geometris pada Pokok Bahasan Segiempat dengan Teori Van Hiele dan Pendekatan PMRI. Seminar Nasional Matematika dan Pendidikan Matematika (hal. 534542). Yogyakarta: Universitas Negeri Yogyakarta.

Yadil, M. N. (2009). Penerapan Model Pembelajaran Van Hiele untuk Meningkatkan Pemahaman Siswa SMP Karunadipa Palu Terbadap Konsep Bangun-bangun Segiempat. Dipetik Oktober 25, 2015, dari http://eprints.uny.ac.id/7015/1/PI-MF.Nur.Yadil.pdf

Yeni, E. M. (2011). Pemanfaatan Benda-Benda Manipulatif untuk Meningkatkan Pemahaman Konsep Geometri dan Kemampuan Tilikan Ruang Siswa Kelas V Sekolah Dasar. Edisi Khusus.

Zulkardi. (2002). Developing a Learning Environment on Realistic Mathematics Education for Indonesian Student Teachers. Enschede: University of Twente. 